\title{
FATTY ACIDS INTAKE AND DEPOSITION IN THE LONGISSIMUS OF NELLORE STEERS SUPPLEMENTED AT PASTURE
}

\author{
CONSUMO E DEPOSIÇÃO DE ÁCIDOS GRAXOS NO LONGISSIMUS DE NOVILHOS \\ NELORE SUPLEMENTADOS EM PASTAGENS
}

\author{
Oliveira, A.P. ${ }^{1}$; Silva, R.R. ${ }^{1}$; Souza, S.O. ${ }^{1}$; Carvalho, G.G.P. ${ }^{1}$; Silva,F.F. ${ }^{1}$; Lisboa,M.M. ${ }^{1}$; \\ Pereira,M.M.S. ${ }^{1}$; Carvalho, V.M. ${ }^{1}$; Mendes, F.B.L. ${ }^{1}$ and Oliveira, A.C. ${ }^{2}$
}

1Universidade Estadual do Sudoeste da Bahia.UESB. Itapetinga, BA. Brasil. araceleprates@hotmail.com ${ }^{2}$ Universidade Federal de Alagoas. UFAL. Brasil.

\section{AdDitiONAL KEYWORDS}

Monounsaturated fatty acids. Polyunsaturated fatty acids. Saturated fatty acids. Ruminants.

\section{SUMMARY}

The aim of this work was to study the correlation between intake and deposition of fatty acids in the Longissimus muscle of Nellore steers supplemented at pasture. The fieldwork was implanted in an area of 52 ha, formed of Brachiaria brizantha. Forty Nellore steers with initial average weight of $373.7 \pm 14.9 \mathrm{~kg}$ and 26 months of age were used. The animals were distributed into four treatments: Control= T00 (supply only mineral salt), T03= Supply of concentrate in the amount of $0.3 \%$ of Body Weight; T06 = Supply of concentrate in the amount of $0.6 \%$ of Live Weight, T09= Supply of concentrate in the amount of $0.9 \%$ of live weight. Samples of concentrates and forages were collected for fatty acids analysis. The experiment lasted for 98 days. After this period the animals were slaughtered. Longissimus samples were vacuum packed and frozen for analysis of fatty acid composition. The results were statistically analyzed by estimating Pearson linear correlation coefficients. The results showed that there are correlations between the fatty acids consumed and fatty acids deposited in the muscle.

\section{RESUMO}

Objetivou-se estudar a correlação entre consumo e deposição de ácidos graxos no músculo Longissimus de novilhos nelore suplementados em pastagens. O trabalho de campo foi implantado numa área de 52 ha, formada de Brachiaria

\section{Palavras chave adicionais}

Ácidos graxos monoinsaturados. Ácidos graxos poliinsaturados. Ácidos graxos saturados. Ruminantes.

brizantha. Foram utilizados 40 novilhos da raça Nelore com peso inicial médio de $373,7 \pm 14,9 \mathrm{~kg}$ e 26 meses de idade, distribuídos em quatro tratamentos: Controle $=$ T00 (fornecimento apenas de sal mineral), $\mathrm{T} 03=$ fornecimento de $0,3 \%$ concentrado em função do peso vivo; T06= fornecimento de $0,6 \%$ concentrado em função do peso vivo; T09= fornecimento de 0,9\% concentrado em função do peso vivo. Amostras dos concentrados e da forragem foram coletadas para análise da composição de ácidos graxos. O período experimental foi de 98 dias. Após este período, os animais foram abatidos. Os resultados foram analisados por correlação linear de Pearson e teste t. Constatou-se que existem correlações entre os ácidos graxos consumidos e depositados no músculo.

\section{INTRODUCTION}

Lipids from diets are of great interest for the scientific community due to its role in human health. Studies show that diets that contain a higher proportion of polyunsaturated fatty acids (PUFA) $v s$. saturated fatty acids (SFA), lead to the reduction of serum cholesterol related to the incidence of atherosclerosis (Nunes, 1995).

In this context, products of animal origin 


\section{OLIVEIRA ETAL.}

such as meat have always been associated with a variety of diseases in humans, and their consumption is associated with increased cardiovascular disease due to its high content of SFA in their composition.

The SFA increase levels of low density lipoprotein (LDL) by reducing its circulation clearance. The elevation of LDL cholesterol fraction in the blood promotes lipid deposits in the vessel walls, causing the appearance of atheromatous plaques, thereby increasing the possibility of the occurrence of a heart attack (Castro et al., 2004).

However, it is known that not all SFA affect cholesterol concentrations the same way. One example is the stearic acid that, unlike the other SFA, is not associated with increased serum levels of lipoproteins, especially LDL, as once inside the body it is rapidly converted into oleic acid (monounsaturated). Polyunsaturated and monounsaturated lipids are related to lower risks of heart disease because they are precursors of substances essential to life, such as prostaglandins, steroids and hormones (Martin et al., 2006).

There are many factors that affect the final quality of the food in view of the fatty acids profile (Herrera Zurita et al., 2011). In products from ruminants, among other factors, we may highlight the type of feed given to animals. Many authors, among who are French et al. (2000), Felton and Kerley (2004), Nuernberg et al. (2005), obtained changes to beef fatty acids by changing the composition of animals' diet.

However, there are no studies in the literature that make a correlation between the lipids in the diet with the lipid present in the muscle of the animals. The study of the correlation between fatty acids found in the animals' diet and those found in the Longissimus muscle may provide subsidies for the formulation of special diets that aim for the deposition of fatty acids essentially important to human health.

Within this context, the objective of this work was to study the correlation between intake and deposition of fatty acids in Longissimus muscle of Nellore steers supplemented at pasture.

\section{MATERIAL AND METHODS}

The experiment was carried out at Fazenda Boa Vista, at Macaraní, Southwest of Bahia. Laboratory tests were conducted at Laboratory of Food Analysis, Department of Chemistry of Universidade Estadual de Maringá - UEM and at Animal Nutrition Laboratory of Department of Rural and Animal Technology of Universidade Estadual do Sudoeste da Bahia-UESB.

Forty Nellore steers with initial average weight of $373.7 \pm 14.9 \mathrm{~kg}$ and 26 months of age were used. The animals were distributed into four treatments: Control= T00 (supply only mineral salt), T03= Supply of concentrate in the amount of $0.3 \%$ of Body Weight; T06 $=$ Supply of concentrate in the amount of $0.6 \%$ of Live Weight, T0= Supply of concentrate in the amount of $0.9 \%$ of live weight. The experiment lasted for 198 days, being 14 days destined to adaptation. The animals were slaughtered with an average final live weight of $455.70 \mathrm{~kg}$. The supplementation was provided daily in plastic troughs without cover. The supplement was provided once a day and always at the same time $(10 \mathrm{~h})$. The proportion of ingredients and chemical composition of experimental diets are presented in table $\mathbf{I}$.

The fieldwork was implanted in an area of 52 ha, divided into eight paddocks of approximately 6.3 ha each. The area was formed by Brachiaria brizantha, spp Marandu, subdivided into pizza format with a central water supply system. The pasture was evaluated every 28 days. The composition of fatty acids consumed in the experimental diets is presented in table II.

Estimates of nutrient intake were conducted in two periods during the experimental trial, lasting 10 days. The first seven days were destined to animal adaptation and stabilization of the flow indicators as 
described by Titgemeyer et al. (2001). To evaluate the bromatological composition of forage consumed we used the simulated grazing. The samples were obtained during the digestibility essays.

To estimate the fecal excretion (FE) was used chromic oxide as external marker as recommended by Smith and Reid (1955), which was applied in a single daily dose (10 $\mathrm{g}$ /animal) packed in paper cartridge. After the seven adaptation days the fecal samples were collected from the animals on the eighth (4 pm), ninth (12 pm) and tenth (8 am) days. The fecal excretion (FE) calculation was carried out based on the ration between the amount of indicator provided and its

Table I. Proportion of ingredients and chemical composition of experimental diets in \% dry matter (DM). (Proporção de ingredientes e composição química das dietas experimentais com base na matéria seca).

\begin{tabular}{lcccc}
\hline Ingredient (\%) & & & & \\
& T00 & T03 & T06 & T09 \\
\hline Corn meal & - & 89.98 & 95.11 & 87.98 \\
Soybean meal & - & - & - & 10.40 \\
Urea & - & 5.00 & 2.44 & 0.06 \\
Mineral salt* & 100 & 5.02 & 2.45 & 1.56 \\
& & & & \\
Chemical composition (\%) & & & \\
& Brachiaria & T03 & T06 & T09 \\
\multicolumn{5}{l}{} \\
Dry matter & 67.93 & 93.54 & 94.12 & 95.23 \\
Crude protein & 6.09 & 22.49 & 15.61 & 13.30 \\
Ether extract & 2.20 & 3.61 & 3.73 & 3.92 \\
Chot & 85.61 & 68.02 & 77.30 & 80.04 \\
NFC & 1.31 & 55.78 & 64.37 & 66.68 \\
NDF & 84.30 & 12.24 & 12.93 & 13.36 \\
ADF & 46.00 & 4.14 & 4.38 & 5.12 \\
Ash & 6.10 & 5.88 & 3.36 & 2.74 \\
TDN & 61.02 & 76.06 & 80.62 & 82.97 \\
& & & & \\
\hline
\end{tabular}

$\mathrm{NFC}=$ Non-fibrous carbohydrates; $\mathrm{NDF}=$ Neutral detergent fiber; $A D F=$ Acid detergent fiber; TDN= Total digestible nutrients.

${ }^{*}$ Composition: Ca 13.2\%; P 4.4\%; Mg 0.5\%; S 1.2\%; Na $17.8 \%$; Se $0.0012 \%$; Cu $0.125 \%$; Zn $0.03 \%$; Mn $0.075 \%$; I $0.005 \%$; Co $1.07 \%$. concentration in feces, according to the equation:

$$
\mathrm{FE}=(\mathrm{I} / \mathrm{CIFe}) \times 100
$$

where:

$\mathrm{I}=$ amount of indicator provided $(\mathrm{g})$;

$\mathrm{CIFe}=$ concentration of indicator in feces $(\%)$.

The dry matter intake (DMI) was estimated by the relationship between FE and diet indigestibility, utilized with indicator internal the indigestible acid detergent fiber (iADF) obtained after 264 hours of incubation in situ (Casali et al., 2008), through the equation:

$$
\mathrm{DMI}=\{[(\mathrm{FE} \times \mathrm{CIFe})-\mathrm{CIS}] / \mathrm{CIFOR}\}+\mathrm{IDMS}
$$

where:

$\mathrm{FE}=$ fecal excretion;

$\mathrm{CIFe}=$ concentration of indicator in feces $(\%)$;

$\mathrm{CIS}=$ concentration of indicator $(\mathrm{iADF})$ on the supplement $(\mathrm{kg} /$ day);

CIFOR= concentration of iADF in forage $(\mathrm{kg} / \mathrm{kg})$; IDMs = intake of MS supplement ( $\mathrm{kg} /$ day).

Titanium dioxide ( $10 \mathrm{~g}$ per animal) was used to determine individual supplement intake (IDMs), mixed to the supplement immediately before it was provided to the animal, according to procedure described by Valadares Filho et al. (2006). The same feces collection scheme was followed as described for chromium oxide, through the equation:

$$
\mathrm{IDMs}=(\mathrm{EF} \times \mathrm{CIFe}) / \mathrm{CIS}
$$

where:

$\mathrm{CIFe}$ and $\mathrm{CIS}$ refer to the concentration of titanium dioxide in feces and supplement, respectively.

The animals were slaughtered at Frigorific Bertin in the city of Itapetinga. Longissimus samples were vacuum packed and frozen, in order to be timely analyzed as regards fatty acids composition. Total lipids were determined following the method 


\section{OLIVEIRA ETAL.}

adapted from Bligh and Dyer (1959). The transesterification of triacylglycerols (TAGs) to obtain fatty acids methyl esters was performed according to ISO method (1978).

The fatty acids methyl esters were analyzed using a gas chromatograph Shimadzu 14-A, equipped with flame ionization detector and fused silica capillary column ( $100 \mathrm{~m}$ long, $0.25 \mathrm{~mm}$ internal diameter and $0.20 \mathrm{~mm}$ in CP-Sil88, Chrompack). The gas fluxes were $1.2 \mathrm{~mL} / \mathrm{min}$ for the carrier gas $\mathrm{H} 2,30 \mathrm{~mL} / \mathrm{min}$ for auxiliary gas $\mathrm{N} 2,30$ and $300 \mathrm{~mL} / \mathrm{min}$ for the flame gases $\mathrm{H} 2$ and synthetic air, respectively. Injector and detector temperatures were 220 and $245^{\circ} \mathrm{C}$, respectively. The column temperature was $140^{\circ} \mathrm{C}$ for $5 \mathrm{~min}$, and then rose to $225^{\circ} \mathrm{C}$ at a rate of $4{ }^{\circ} \mathrm{C} / \mathrm{min}$. The sample's division ratio was 1: 100. Peak areas were determined by the standardization method, using an

Table II. Composition of fatty acids consumed in the experimental diets (\%). (Composição de ácidos graxos consumidos nas dietas experimentais (\%)).

\begin{tabular}{lcccc}
\hline Fatty acids & Brachiaria & T03 & T06 & T09 \\
\hline C14: 0 & 1.13 & - & - & - \\
C16: 0 & 18.92 & 15.79 & 14.85 & 12.37 \\
C18: 0 & 5.81 & 4.57 & 4.72 & 6.10 \\
C18: $1 \mathrm{n}-9$ & 16.79 & 44.40 & 42.75 & 35.03 \\
C18: $1 \mathrm{n}-7$ & 4.24 & 1.95 & 3.29 & 2.17 \\
C18: $2 \mathrm{n}-6$ & 34.63 & 27.64 & 28.60 & 41.83 \\
C18: $3 \mathrm{n}-6$ & 1.41 & 1.91 & 1.81 & 0.67 \\
C18: $3 \mathrm{n}-3$ & 9.55 & 0.86 & 0.85 & 0.83 \\
C20: $4 \mathrm{n}-6$ & 1.67 & 0.89 & 0.93 & 0.28 \\
C20: $5 \mathrm{n}-3$ & 1.76 & 0.37 & 0.55 & 0.14 \\
C22: $5 \mathrm{n}-3$ & 2.64 & 1.37 & 1.35 & 0.35 \\
C22: $6 \mathrm{n}-3$ & 1.48 & 0.26 & 0.31 & 0.24 \\
PUFA & 53.13 & 33.29 & 34.39 & 44.33 \\
MUFA & 21.03 & 46.35 & 46.04 & 37.20 \\
SFA & 25.85 & 20.36 & 19.57 & 18.47 \\
n-6 & 37.71 & 30.43 & 31.34 & 42.78 \\
n-3 & 15.42 & 2.86 & 3.06 & 1.55 \\
PUFA: SFA & 2.06 & 1.64 & 1.76 & 2.40 \\
n-6/n-3 & 2.45 & 10.73 & 10.66 & 27.91 \\
\hline
\end{tabular}

Table III. Fatty acid composition (\%) of Longissimus muscle from Nellore steers supplemented in pastures. (Composição em ácidos graxos do músculo Longissimus de novilhos Nelore suplementados em pastagens).

\begin{tabular}{lcccc}
\hline Fatty acids & T00 & T03 & T06 & T09 \\
C14: 0 & 1.98 & 2.17 & 2.43 & 2.14 \\
C14: $1 \mathrm{n}-9$ & 0.31 & 0.37 & 0.40 & 0.34 \\
C15: 0 & 0.31 & 0.32 & 0.33 & 0.27 \\
C15: $1 \mathrm{n}-9$ & 0.16 & 0.17 & 0.17 & 0.16 \\
C16: & 23.61 & 24.59 & 24.76 & 22.66 \\
C16: $1 \mathrm{n}-9$ & 0.53 & 0.49 & 0.50 & 0.51 \\
C16: $1 \mathrm{n}-7$ & 1.72 & 1.94 & 1.83 & 1.61 \\
C16: $1 \mathrm{n}-5$ & 0.70 & 0.73 & 0.72 & 0.70 \\
C17: 0 & 0.92 & 0.94 & 0.94 & 0.94 \\
C17: $1 \mathrm{n}-9$ & 0.80 & 0.76 & 0.74 & 0.67 \\
C18: 0 & 17.12 & 17.64 & 17.73 & 20.03 \\
C18: $1 \mathrm{n}-9$ & 36.22 & 36.97 & 36.69 & 36.42 \\
C18: $1 \mathrm{n}-7$ & 3.06 & 2.68 & 2.20 & 2.78 \\
C18: $1 \mathrm{t11}$ & 1.31 & 1.38 & 1.29 & 1.34 \\
C18: $2 \mathrm{n}-6$ & 4.64 & 3.90 & 4.09 & 4.35 \\
C18: $3 \mathrm{n}-6$ & 0.13 & 0.12 & 0.13 & 0.18 \\
CLA & 0.38 & 0.32 & 0.38 & 0.38 \\
C18: $3 \mathrm{n}-3$ & 1.26 & 1.02 & 1.09 & 0.81 \\
C20: $4 \mathrm{n}-6$ & 2.28 & 1.49 & 1.63 & 1.75 \\
C20: $5 \mathrm{n}-3$ & 0.88 & 0.53 & 0.57 & 0.49 \\
C22: 0 & 0.51 & 0.34 & 0.38 & 0.47 \\
C22: $5 \mathrm{n}-3$ & 0.16 & 0.13 & 0.27 & 0.15 \\
C22: $6 \mathrm{n}-3$ & 1.47 & 1.02 & 0.93 & 0.86 \\
PUFA & 11.13 & 8.56 & 8.94 & 8.97 \\
MUFA & 44.42 & 45.48 & 44.49 & 44.52 \\
SFA & 44.45 & 46.01 & 46.57 & 46.52 \\
n-3 & 3.76 & 2.69 & 2.74 & 2.32 \\
n-6 & 7.04 & 5.51 & 5.82 & 6.27 \\
PUFA: SFA & 0.25 & 0.19 & 0.19 & 0.20 \\
n-6/n-3 & 1.93 & 2.05 & 2.16 & 2.79 \\
\hline & & & & \\
\hline & & & &
\end{tabular}

integrator-processor CG-300. The peaks were identified by comparing retention times of methyl esters standards of Sigma fatty acids (USA). Fatty acids composition of Longissimus muscle is presented in table III.

For data analysis Pearson linear correlation test was performed between the composition of the fatty acids consumed with the composition of fatty acids found in muscle. The significance of the correlation coefficient was tested using the t test at $5 \%$ 
probability using the statistical package SAEG(UFV, 2000).

\section{RESULTSANDDISCUSSION}

Of the fatty acids found in the diet provided to animals may highlight the polyunsaturated, which can be verified by the high relationship between polyunsaturated and saturated fatty acids (PUFA/SFA) seen in table II. In the muscle examined, the incidence is predominantly of saturated fatty acids, indicated by the low PUFA/SFA (table III).

The analysis between fatty acids contained in the diet and deposited in the muscle indicated that there was a correlation between palmitic (C16: 0), stearic(C18:0), cis-vaccenic (18: $111 \mathrm{C})$, gamma-linolenic (C18: $3(\omega-6))$, alpha-linolenic(18: 3n-3), eicosapentaenoic 20: $5(\omega-3)$ (EPA) and docosahexaenoic acids (DHA)(C22: 6), as well as the sums of SFA and omega-3 and relationship of omega- 6 and omega-3 (n-6/ $\mathrm{n}-3$ ), with fatty acids found in the diet (table IV).

The correlation between the SFA found in the experimental diets with fatty acids deposited in the muscle can be seen in table IV. There were correlations between the fatty acids mentioned above, found in the muscle, with myristic (C14: 0), palmitic (C16: $0)$ and stearic (C18: 0) acids of the diet.

The myristic and palmitic acids present in the animals' diet presented, respectively, negative correlations with stearic $(\mathrm{r}=-0.59$; $\mathrm{p}=0.001 ; \mathrm{r}=-0.68 ; \mathrm{p}=0.001)$ and gammalinolenic $(r=-0.47 ; p=0.012 ; r=-0.57 ; p=$ $0.002)$ acids, as well as with total SFA(r= $-0.42 ; \mathrm{p}=0.024 ; \mathrm{r}=-0.36 ; \mathrm{p}=0.045)$ and with the ration $\mathrm{n}-6 / \mathrm{n}-3(\mathrm{r}=-0.69 ; \mathrm{p}=0.002$; $\mathrm{r}=-0.76 ; \mathrm{p}=0.001$ ) found in the muscle. However, positive correlations were found between the myristic and palmitic acids in relation to alpha-linolenic acid $(\mathrm{r}=0.45 ; \mathrm{p}=$ $0.016 ; r=0.47 ; p=0.012)$, EPA $(r=0.43 ; p=$ $0.020 ; r=0.36 ; p=0.047)$, DHA $(r=0.44 ; p=$ $0.448 ; \mathrm{r}=0.37 ; \mathrm{p}=0.044)$ and total omega-3 $(\mathrm{r}=0.46 ; \mathrm{p}=0.015 ; \mathrm{r}=0.41 ; \mathrm{p}=0.028)$, respectively, found in the muscle.

These results are quite interesting; especially the positive correlations with fatty acids of omega-3 series in contrast with the negative correlations with those of omega- 6 series, as well as the ratio between the two.

Fatty acids of the families n- 6 and n-3 are not synthesized by the human body and must be obtained from the diet (Martin et al., 2006). They are considered essential because from them long chain polyunsaturated fatty acids are synthesized such as arachidonic acid (AA), EPA and DHA, which play important roles in cardiovascular protection, development and functioning of the brain and retina (Martin et al., 2006). There is competition between fatty acids of families n-6 and n-3 for the enzymes involved in the reactions of desaturation and elongation of the chain; therefore there must be a balanced intake of n- 6 and n-3, since an excess of $n-6$ could prevent, because of the

Table IV. Correlation between saturated fatty acids of the diet with fatty acids in Longissimus muscles of Nellore steers supplemented in pastures. (Correlação entre os ácidos graxos saturados da dieta com ácidos graxos no músculo Longissimus de novilhos Nelore suplementados em pastagens).

\begin{tabular}{|c|c|c|c|c|c|c|}
\hline & \multicolumn{6}{|c|}{ Diet fatty acids } \\
\hline & \multicolumn{2}{|c|}{ C14: 0} & \multicolumn{2}{|c|}{ C16: 0} & \multicolumn{2}{|c|}{ C18: 0} \\
\hline & r & $p$ & r & $p$ & $r$ & $p$ \\
\hline \multicolumn{7}{|c|}{ Muscle fatty acids } \\
\hline C16:0 & - & - & - & - & 0.47 & 0.012 \\
\hline C18:0 & -0.59 & 0.001 & -0.68 & 0.001 & 0.38 & 0.037 \\
\hline C18:1n-7 & - & - & - & - & 0.49 & 0.009 \\
\hline C18:3n-6 & -0.47 & 0.012 & -0.57 & 0.002 & 0.42 & 0.024 \\
\hline C18:3n-3 & 0.45 & 0.016 & 0.47 & 0.012 & - & - \\
\hline$C 20: 5 n-3$ & 0.43 & 0.020 & 0.36 & 0.047 & - & - \\
\hline$C 22: 6 n-3$ & 0.44 & 0.448 & 0.37 & 0.044 & - & - \\
\hline SFA & -0.42 & 0.024 & -0.36 & 0.045 & - & - \\
\hline$n-3$ & 0.46 & 0.015 & 0.41 & 0.028 & - & - \\
\hline$n-6 / n-3$ & -0.69 & 0.002 & -0.76 & 0.001 & 0.39 & 0.035 \\
\hline
\end{tabular}




\section{OLIVEIRA ETAL.}

competition, the transformation of the fatty acid from omega-3 series into their long chain derivatives, such as EPA and DHA, substances associated with antiinflammatory effects in the blood (Martin et al., 2006).

Thus, while myristic and palmitic acids induce the increase of cholesterol in the blood, being reported as the primarily responsible for hypercholesterolemic effect of saturated fatty acids (Griinari et al., 1995), the negative correlation of these substances in the diet of the animals with ratio n-6/n-3 and the total sum of SFA, as well as the positive correlation with the same alphalinolenic acid found in muscle, appears to be highly satisfactory from the human health standpoint.

The diet's stearic acid presented positive correlation with palmitic $(\mathrm{r}=0.47 ; \mathrm{p}=0.012)$, stearic $(\mathrm{r}=0.38 ; \mathrm{p}=0.037)$, cis-vaccenic $(\mathrm{r}=$ $0.49 ; \mathrm{p}=0.009)$, and gamma-linolenic $(\mathrm{r}=0.42$; $\mathrm{p}=0.024$ ) acids, as well as with ration $\mathrm{n}-6 / \mathrm{n}-3$ $(\mathrm{r}=0.39 ; \mathrm{p}=0.035)$ in the muscle (table IV).

Although there was no correlation between the diet's stearic acid and the muscle's oleic acid, there was a correlation with the muscle's stearic acid. This is interesting as the stearic acid acts on cholesterol decrease resulting in a quick conversion into oleic acid. Bonanome and Grundy (1988) described that diets rich in oleic acids provided a reduction of total plasmatic cholesterol, LDL cholesterol percentage, and in the relation between LDL and HDL cholesterol, showing the positive effect of this substance in humans.

The correlation between monounsaturated fatty acids (MUFA), found in experimental diets, with fatty acids deposited in the muscle can be seen in table $\mathbf{V}$. The oleic acid present in the diet presented positive correlations with stearic acid $(\mathrm{r}=0.45 ; \mathrm{p}=$ $0.015)$, with the sum of SFA $(r=0.42 ; p=$ $0.025)$ and ratio $n-6 / n-3(r=0.55 ; p=0.003)$.

The positive correlation of this compound with stearic acid and total SFA in the muscle can be the result of the biohydrogenation process, where unsaturated fatty acids are converted into saturated fatty acids, as unsaturated fatty acids are toxic to rumen microbial (Medeiros, 2003).

The diet's oleic acid also presented moderate and negative correlation with EPA $(\mathrm{r}=-0.44 ; \mathrm{p}=0.019), \mathrm{DHA}(\mathrm{r}=-0.46 ; \mathrm{p}=0.014)$ and total $\mathrm{n}-3(\mathrm{r}=-0.44 ; \mathrm{p}=0.018)$ found in the muscle. The oleic acid can compete with alpha-linolenic acid and its intermediates for the reactions mediated by desaturase and elongases (Martin et al., 2006). The alpha-linolenic acid, via the desaturase and elongases enzymes, is a precursor of EPA and DHA. These fatty acids belong to the n3 family; consequently, there was a negative correlation between the oleic acid of the diet with the total n-3 total of the muscle, as well as a moderate and positive correlation with ratio $n-6 / n-3(r=0.55 ; p=0.003)$ found in the muscle.

The diet's cis-vaccenic acid, a monounsaturated fatty acid common in bacteria and present in small amounts in tissues of

Table $V$. Correlation between the diet's monounsaturated fatty acids and fatty acids in Longissimus muscle of Nellore steers supplemented in pasture. (Correlação entre ácidos graxos monoinsaturados da dieta e ácidos graxos no músculo Longissimus de novilhos Nelore suplementados em pastagens).

\begin{tabular}{|c|c|c|c|c|}
\hline & \multicolumn{4}{|c|}{ Diet fatty acids } \\
\hline & \multicolumn{2}{|c|}{ C18: 1n-9 } & \multicolumn{2}{|c|}{ C18: 1n-7 } \\
\hline & $r$ & $\mathrm{P}$ & $r$ & $P$ \\
\hline \multicolumn{5}{|c|}{ Muscle fatty acids } \\
\hline C16:0 & - & - & - & - \\
\hline C18:0 & 0.45 & 0.015 & 0.64 & 0.001 \\
\hline C18:1n-7 & - & - & - & - \\
\hline C18:3n-6 & - & - & -0.57 & 0.002 \\
\hline C18:3n-3 & - & - & 0.48 & 0.010 \\
\hline$C 20: 5 n-3$ & -0.44 & 0.019 & 0.39 & 0.034 \\
\hline C22:6n-3 & -0.46 & 0.014 & 0.36 & 0.049 \\
\hline SFA & 0.42 & 0.025 & - & - \\
\hline -3 & -0.44 & 0.018 & - & - \\
\hline$n-6 / n-3$ & 0.55 & 0.003 & -0.77 & 0.001 \\
\hline
\end{tabular}


plants and animals, presented moderate and positive correlation with stearic acid ( $\mathrm{r}=$ $0.64 ; \mathrm{p}=0.001)$ found in muscle, indicating that probably there was not full of biohydrogenation in the rumen (table V).

The diet's cis-vaccenic acid also presented moderate and negative correlation with the gamma-linolenic acid $(\mathrm{r}=$ $-0.57 ; \mathrm{p}=0.002$ ) found in the muscle, thus indicating that its presence in the diet may have contributed to decrease the deposition of gamma-linolenic acid in the muscle (Wood et al., 2004). This substance also presented moderate and positive correlation with alpha-linolenic acid $(r=0.48 ; \mathrm{p}=0.010)$. This positive correlation may be the main reason why positive, albeit weak, correlations were found between this acid with EPA $(r=0.39$; $\mathrm{p}=0.034)$ and DHA $(\mathrm{r}=0.36 ; \mathrm{p}=0.049)$, consequently resulting in a moderate and positive correlation with total $n-3(r=0.41$; $\mathrm{p}=0.025)$ as well as a strong and negative correlation with ratio $n-6 / n-3(r=-0.77 ; p=$ 0.001 ) found in the muscle.

The table VI presents the correlations

Table VI. Correlation between polyunsaturated fatty acids of diet with the fatty acids of the Nellore steers' Longissimus muscle supplemented in pasture. (Correlação entre ácidos graxos poliinsaturados da dieta com os ácidos graxos do músculo Longissimus de novilhos Nelore suplementados em pastagens).

\begin{tabular}{|c|c|c|c|c|c|c|}
\hline & \multicolumn{6}{|c|}{ Diet fatty acids } \\
\hline & \multicolumn{2}{|c|}{ C18: $2 n-6$} & \multicolumn{2}{|c|}{ C18: 3n-6 } & \multicolumn{2}{|c|}{ C18: $3 n-3$} \\
\hline & $\mathrm{r}$ & $p$ & $\mathrm{r}$ & $p$ & $\mathrm{r}$ & $p$ \\
\hline \multicolumn{7}{|c|}{ Muscle fatty acids } \\
\hline C16:0 & -0.47 & 0.013 & 0.47 & 0.013 & - & - \\
\hline C18:0 & 0.57 & 0.002 & -0.61 & 0.001 & -0.59 & 0.001 \\
\hline C18:3n-6 & 0.56 & 0.002 & -0.59 & 0.001 & -0.47 & 0.012 \\
\hline C18:3n-3 & - & - & 0.37 & 0.043 & 0.45 & 0.016 \\
\hline C20:5n-3 & - & - & - & - & 0.42 & 0.022 \\
\hline$C 22: 6 n-3$ & - & - & - & - & 0.44 & 0.019 \\
\hline SFA & - & - & - & - & -0.40 & 0.029 \\
\hline$n-3$ & - & - & - & - & 0.45 & 0.017 \\
\hline$n-6 / n-3$ & 0.63 & 0.001 & -0.67 & 0.001 & -0.69 & 0.001 \\
\hline
\end{tabular}

between polyunsaturated fatty acids (PUFA) linolenic (C18: 2n-6), gammalinolenic (C18: 3n-6) and alpha-linolenic (C18:3n-3), found in experimental diets with fatty acids deposited in the muscles.

In ruminants, a significant proportion of unsaturated fatty acids are biohydrogenated in the rumen before being absorbed. The bacteria responsible for biohydrogenation can be divided into two groups: group A is represented by bacteria of the genus Butyrivibrio sp. and group B is represented by bacteria of the genus Fusocillus sp. The first group is responsible for the biohydrogenation of linoleic acid (18:2n-6) and alpha-linolenic acid (18:3n3 ) into trans-vaccenic acid (18: $1 \mathrm{t} 11)$, with small amounts of other isomers. This group seems unable to bio-hydrogenate oleic fatty acid into stearic acid. On the other hand, bacteria in the second group are able to biohydrogenate a wide range of cis and trans C18: 1 into C18: 0 (Demeyer and Doreau, 1999).

In this study, the diet's linoleic acid correlated moderately and negatively with palmitic acid $(r=-0.47 ; p=0.013)$ found in the muscle, thus indicating that their presence may have contributed to a decrease of saturated fatty acid deposition in the muscle.

The diet's linolenic acid also presented moderate and positive correlation with the stearic acid found in the muscle $(r=0.57 ; p=$ $0.002)$. This relation was already expected as the linoleic acid suffers isomerization and is transformed into rumenic acid (C18:2 cis9 trans11) during biohydrogenation. Later it suffers a reduction and is converted into vaccenic acid (C18: 1 trans11) and, finally, into stearic acid (C18:0).

A moderate and positive correlation was also found between the linoleic acid of the diet and the gamma-linolenic acid $(r=0.56$; $\mathrm{p}=0.002)$ and with ratio $\mathrm{n}-6 / \mathrm{n}-3(\mathrm{r}=0.63 ; \mathrm{p}=$ 0.001 ) found in the muscle. This finding may indicate the desaturation of the linoleic acid by the action of $\omega-6$ desaturase enzyme, found in the endoplasmatic reticulum of 


\section{OLIVEIRA ETAL.}

animal cells, the gamma-linolenic acid (Martin et al., 2006).

Was also found a correlation between the diet's gamma-linolenic acid with some fatty acids present in the muscle. Positive and moderate correlations were found for palmitic $(\mathrm{r}=0.47 ; \mathrm{p}=0.013)$ and gammalinolenic moderate and negative correlation $(\mathrm{r}=-0.59 ; \mathrm{p}=0.001)$ acids, found in the muscle. It is possible that the ability of the microorganisms to saturate the gammalinolenic acid has been compromised. This led to a greater flow to the abomasum, reaching the intestine and then absorbed and deposited in the muscle.

The diet's gamma-linolenic acid presented weak and positive correlation with the alpha-linolenic acid $(r=0.37 ; p=0.043)$ found in the muscle, thus indicating that its presence in the diet may have contributed to increase the deposition of alpha-linolenic acid in the muscle. Consequently, we observed a moderate and negative correlation between the diet's alpha-linolenic with ratio $n-6 / n-3(r=-0.67 ; p=0.001)$ found in the muscle.

Several factors can affect the process of biohydrogenation, including diet composition, breed and management system (Enser et al., 1998, Monteiro, 1998; Sañudo et al., 2000; Wood etal., 2004; Demirel et al., 2006). A diet based on concentrate and therefore with large numbers of rapidly degradable carbohydrates, promotes a lower retention time of food in the rumen and therefore a shorter time of action of the process of biohydrogenation on polyunsaturated fatty acids. The diet fed to the animals had higher concentrations of nonfibrous carbohydrates, which probably may have modified the $\mathrm{pH}$ and thus the microbial population responsible for biohydrogenation.

The diet's alpha-linolenic acid correlated moderately and negatively with stearic $(\mathrm{r}=$ $-0.59 ; \mathrm{p}=0.001)$ and with gamma-linolenic $(\mathrm{r}=-0.47 ; \mathrm{p}=0.012)$ acids found in muscle. This results indicate that there was no biohydrogenation of the alpha-linolenic acid into stearic acid, and also that certainly the competition of the desaturase enzymes by the enzymes of n-3 family against n- 6 family was preferential to $n-3$ family, as the correlation was negative with gammalinoleic acid and positive with alpha-linolenic acid $(r=0.45 ; p=0.016)$. The presence of the alpha-linolenic acid in the diet may have decreased the gamma-linolenic acid deposition in the muscle. Families n-3 and n6 compete for the same enzymes in the metabolic pathway and the $n-3$ have higher affinity for the enzymes (Kelley, 2001). Thus, a diet rich in n-3 may have affected the deposition of n- 6 family acids in the muscle.

The alpha-linolenic acid diet showed moderate and positive correlation with EPA $(\mathrm{r}=0.42 ; \mathrm{p}=0.022)$ and DHA $(\mathrm{r}=0.44 ; \mathrm{p}=$ 0.019 ) found in the muscle, which is consistent with positive alpha-linolenic deposition correlation. The alpha-linolenic acid is an essential fatty acid, i.e., it must be obtained through the diet because mammals, including humans, are unable to synthesize it. Once ingested it can be converted into other polyunsaturated acids such as EPA and DHA (Nelson and Cox, 2002). This explains the positive correlation between alpha-linolenic acid diet with EPA and DHA found in muscle.

The alpha-linolenic acid diet correlated moderately and negatively to total SFA ( $\mathrm{r}=$ $-0.40 ; p=0.017$ ) found in muscle. As the correlation of this substance with stearic acid was also negative, possibly indicating that there was no complete biohydrogenation, which would explain the decrease in total SFA in the muscle.

Moderate and positive correlation of alpha-linolenic acid was also found for the sum of $n-3(r=0.45 ; p=0.017)$, resulting in a moderate and negative correlation with ratio $\mathrm{n}-6 / \mathrm{n}-3(\mathrm{r}=-0.69 ; \mathrm{p}=0.001)$ found in the muscle. The alpha-linolenic acid belongs to $n-3$ series. Its presence in the diet favors the deposition of these acids in the muscle and, consequently, the diet's $n-6 / n-3$ ratio 
decreases.

Table VII presents the correlations found between polyunsaturated fatty acids (PUFA) present in the experimental diets with fatty acids deposited in the muscle.

The AA, EPA, docosapentaenoic (DPA) and DHA, found in the experimental diets presented negative correlation with stearic $\operatorname{acid}(\mathrm{r}=-0.50 ; \mathrm{p}=0.007 ; \mathrm{r}=-0.63 ; \mathrm{p}=0.001, \mathrm{r}=$ $-0.67 ; \mathrm{p}=0.001 ; \mathrm{r}=-0.59 ; \mathrm{p}=0.001$; respectively). This finding demonstrates that when these substances are present in the diet they are not changed by rumen microorganisms to the point of biohydrogenation.

Negative correlations were also found between these substances present in the diet with the gamma-linolenic acid. It seems that, although the amount of n- 6 in diets is higher than the amount of n-3 (table II), the enzymatic competition was preferential to the fatty acids of n-3 series, because the fatty acids belonging to this series, present in the diet, presented still more positive correlations with fatty acids also from the n3 series deposited in the muscle. Long chain fatty acids such as $\mathrm{C} 20$ and $\mathrm{C} 22$, belonging to n-3 family, are not prone to modification by rumen microorganisms, which may favor the increase of deposition of these polyunsaturated fatty acids in the muscle, therefore improving the nutritional and functional quality of the meat (Ponnampalametal., 2001).

We also verified strong and negative correlation between AA $(r=-0.73 ; p=0.001)$, $\operatorname{EPA}(\mathrm{r}=-0.76 ; \mathrm{p}=0.001), \operatorname{DPA}(\mathrm{r}=-0.78 ; \mathrm{p}=$ $0.001)$ and DHA $(r=-0.71 ; \mathrm{p}=0.001)$ present in the diet with ratio $n-6 / n-3$ found in the muscle. The n-3 fatty acids inhibit the desaturase enzyme that decreases the production of n- 6 fatty acids. Thus, the increase of $n$-in the diet reduces the ratio n6/n-3 in the muscle. Fatty acids of the n- 6 family produce inflammatory eicosanoids and carcinogens, increasing the risk of cancer, sudden death, heart disease, vasoconstriction, increased blood pressure, increased proportion of triglycerides, arthritis, depression and other inflammatory diseases. Fatty acids of the n-3 family are anti-inflammatory, antithrombotic and antiarrhythmic; they also reduce blood lipids and have vasodilator properties. These beneficial effects were demonstrated in the prevention of heart disease, hypertension,

Table VII. Correlation between diet polyunsaturated fatty acids with Longissimus muscle of Nellore steers supplemented in pasture. (Correlação entre os ácidos graxos poliinsaturados da dieta e do músculo Longissimus de novilhos Nelore suplementados em pastagens).

\begin{tabular}{|c|c|c|c|c|c|c|c|c|}
\hline & \multicolumn{8}{|c|}{ Diet fatty acids } \\
\hline & \multicolumn{2}{|c|}{ C20: 4n-6 } & \multicolumn{2}{|c|}{ C20: $5 n-3$} & \multicolumn{2}{|c|}{ C22: $5 n-3$} & \multicolumn{2}{|c|}{ C22: $6 n-3$} \\
\hline & r & $p$ & r & $p$ & r & $p$ & r & $p$ \\
\hline \multicolumn{9}{|c|}{ Muscle fatty acids } \\
\hline C16: 0 & - & - & - & - & - & - & - & - \\
\hline C18: 0 & -0.50 & 0.007 & -0.63 & 0.001 & -0.67 & 0.001 & -0.59 & 0.001 \\
\hline C18: $3 n-6$ & -0.56 & 0.002 & -0.55 & 0.003 & -0.58 & 0.002 & -0.49 & 0.009 \\
\hline C18: $3 n-3$ & 0.39 & 0.033 & 0.47 & 0.012 & 0.48 & 0.011 & 0.45 & 0.015 \\
\hline C20: $5 n-3$ & - & - & 0.41 & 0.026 & 0.37 & 0.042 & 0.43 & 0.022 \\
\hline C22: $6 n-3$ & - & - & 0.41 & 0.028 & 0.36 & 0.046 & 0.43 & 0.021 \\
\hline SFA & - & - & -0.37 & 0.041 & - & - & -0.40 & 0.032 \\
\hline$n-3$ & - & - & 0.44 & 0.019 & 0.41 & 0.027 & 0.45 & 0.017 \\
\hline$n-6 / n-3$ & -0.73 & 0.001 & -0.76 & 0.001 & -0.78 & 0.001 & -0.71 & 0.001 \\
\hline
\end{tabular}




\section{OLIVEIRA ETAL.}

type 2 diabetes, rheumatoid arthritis and others (Fagundes, 2002).

\section{CONCLUSIONS}

Correlations were found between the fatty acids in the diet of animals with those deposited in their muscles. Such correlations show that the diet provided to animals

\section{REFERENCES}

Bligh, E.G. and Dyer, W.J. 1959. A rapid method of total lipid extraction and purification. Canad $J$ Biochem Physiol, 37: 911-917.

Bonanome, A. and Grundy, S.M. 1988. Effect of dietary stearic acid on plasma cholesterol and lipoprotein levels. New Engl J Med, 318: 1244.

Casali, A.O.; Detmann, E.; Valadares Filho, S.C.; Pereira, J.C.; Henriques, L.T.; Freitas, S.G. and Paulino, M.F. 2008. Influência do tempo de incubação e do tamanho de partículas sobre os teores de compostos indigestíveis em alimentos e fezes bovinas obtidos por procedimentos in situ. Rev Bras Zootecn, 37: 335-342.

Castro, L.C.V.; Franceschini, S.C.C.; Priore, S.E. and Pelúzio, M.C.G. 2004. Nutrition and cardiovascular diseases: the risk markers in adults. Rev. Nutr. Campinas. 369-377.

Demeyer, D. and Doreau, M. 1999. Targets and procedures for altering ruminant meat and milk lipids. Proc Nutr Soc, 58: 593-607.

Demirel, G.; Ozpinar, H. and Nazli, B. 2006. Fatty acids of lamb meat from two breeds fed different forage: concentrate ratio. Meat Sci, 72: 229235.

Enser, M.; Hallett, K.G.; Fursey, A.J.; Wood, J.D. and Harrington, G. 1998. Fatty acid content and composition of UK beef and lamb muscle in relation to production system and implications for human nutrition. Meat Sci. 49: 329-341.

Fagundes, L.A. 2002. Ômega-3 and Ômega-6: o equilíbrio dos ácidos gordurosos essenciais na prevenção de doenças. Fundação de Radioterapia do Rio Grande do Sul. Porto Alegre. pp. 111.

Felton, E.E.D. and Kerley, M.S., 2004. Performance and carcass quality of steers fed different sources of dietary fat. $J$ Anim Sci, 82: 17941805. changed the profile of the fatty acids, increasing fatty acids of n-3 family, reducing SFA and the $n-6 / n-3$ ration in the Longissimus muscle of Nellore steers supplemented in pastures.

\section{ACKNOWLEDGEMENTS}

Banco do Nordeste do Brasil (BNB).
French, P.; Stanton, C.; Lawless, F.; O'riordan, E.G.; Monahan, F.J.; Caffrey, P.J. and Moloney, A.P. 2000. Fatty acid composition, including conjugated linoleic acid of intramuscular fat from steers offered grazed grass, grass silage, or concentrate based diets. J Anim Sci, 78: 2849-2855.

Griinari, J.M.; Bauman, D.E. and Jones, L.R., 1995. Low milk fat in New York Holstein herds. Proc. of Cornell Nutrition Conference. pp. 96-105.

Herrera, P.Z.; Bermejo, J.V.D.; Henríquez, A.A.; Vallejo, M.E.C. and Costa, R.G.2011. Effects of extensive system versus semi-intensive and intensive systems on growth and carcass quality of dairy kids. Rev Bras Zootecn, 40: 2613-2620.

ISO. International Organization for Standardization. 1978. Animal and vegetable fats 551 and oils - Preparation of methyl esters of fatty acids. Method ISO 5509.

Kelley, D.S. 2001. Modulation of human immune and inflammatory responses by dietary fatty acids. Nutrition, 17: 669-673.

Martin, C.A.; Almeida, V.V.; Ruiz, M.R.; Visentainer, J.E.; Matshushita, M.; Souza, N.E. e Visentainer, J.V. 2006. Ácidos graxos poliinsaturados ômega3 e ômega-6: importância e ocorrência em alimentos. Rev Nutr, 19: 761-770.

Medeiros, S.R., 2003. Modulação do perfil lipídico de bovinos: implicações na produção e aceitação da carne. V Simpósio Goiano sobre Manejo e Nutrição de Bovinos de Corte e Leite. CBNA. Goiânia. pp. 43.

Monteiro, E.M. 1998. Influência do cruzamento lle de France $x$ Corriedale (F1) nos parâmetros de qualidade da carne de cordeiro. Tese (Doutorado em Ciência dos Alimentos) Universidade de São Paulo. São Paulo. 99 pp.

Archivos de zootecnia vol. 63, núm. 241, p. 94. 
Nelson, D.L. e Cox, M.M. (Editors). 2002. Lehninger. Princípios de Bioquímica. 3a . ed. Sarvier. São Paulo. 975 pp.

Nuernberg, K.; Dannenberger, D.; Nuernberg, G.; Ender, K.; Voigt, J.; Scollan, N.D.; Wood, J.D.; Nute, G.R. and Richardson, R.I. 2005. Effect of a grass-based and a concentrate feeding system on meat quality characteristics and fatty acid composition of Longissimus muscle in different cattle breeds. Liv Produc Sci, 94: 137-147.

Nunes, I.J. 1995. Nutrição animal básica. Breder. Belo Horizonte. 334 pp.

Ponnampalam, E.N.; Sinclair, A.J.; Egan, A.R.; Blakeley, S.J. and Leury, B.J. 2001. Effect of diets containing $n-3$ fatty acids on muscle longchain n-3 fatty acid content in lambs fed lowand medium-quality roughage diets. J Anim Sci, 79: 698-706.

Sañudo, C.; Enser, M.E.; Campo, M.M.; Nute, G.R.; Maria, G.; Sierra, I. and Wood, J.D. 2000. Fatty acid composition and sensory characteristics of lamb carcasses from Britain and Spain. Meat
Sci, 54: 339-346.

Smith, A.M. and Reid, J.T. 1955. Use of chromic oxide as an indicator of fecal output for the purpose of determining the intake of pasture herbage by grazing cows. J Dairy Sci, 38: 515524.

Titgemeyer, E.C.; Armendariz, C.K. and Bindel, D.J. 2001. Evaluation of titanium dioxide as a digestibility marker for cattle. J Anim Sci, 79: 1059-1063.

Valadares Filho, S.C; Moraes, E.H.B.K. e Detmann, E. 2006. Perspectivas do uso de indicadores para estimar o consumo individual de bovinos alimentados em grupo. Rev Bras Zootecn, (supl esp) 35: 291-322 .

UFV. Universidade Federal de Viçosa. 2000. Sistema de análises estatísticas e genéticas. SAEG. Versão 8.0. Viçosa, MG. 142 pp.

Wood, J.D.; Richardson, R.I.; Nute, G.R.; Fisher, A.V.; Campo, M.M.; Kasapidou, E.; Sheard, P.R. and Enser, M. 2004. Effects of fatty acids on meat quality: a review. Meat Sci, 66: 21-32. 